\title{
FUNKCJE GMINNYCH RAD SENIORÓW
}

I. Gminne rady seniorów są stosunkowo nową instytucją prawną w Polsce. Podstawę prawną ich powołania stanowi ustawa z 21 października $2013 \mathrm{r}$. o zmianie ustawy o samorządzie gminnym ${ }^{1}$. Artykułem 1 tej ustawy znowelizowano ustawę z 8 marca 1990 r. o samorządzie gminnym ${ }^{2}$ przez dodanie art. 5c stanowiącego normatywną podstawę funkcjonowania gminnych rad seniorów w Polsce.

Należy jednak stwierdzić, że gminne rady seniorów powoływane były przez organy gminne przed $2013 \mathrm{r}^{3}$ Jako przykład wskazać można uchwałę nr XXIV/228/V/2007 Rady Miasta Poznania z 25 października 2007 r. w sprawie powołania Miejskiej Rady Seniorów ${ }^{4}$. W uchwale tej stwierdzono, że rada seniorów będzie służyła seniorom poprzez reprezentowanie ich interesów wobec władz Miasta. Jednocześnie wskazano, że rada będzie organem opiniodawczym, doradczym i inicjatywnym dla władz Miasta (§ 1 ust. 2-3). Już wtedy wskazywano w uzasadnieniu uchwały, że rada będzie służyła integracji międzypokoleniowej i partycypacji osób starszych w życiu społecznym.

Nowelizacja ustawy o samorządzie gminnym motywowana była potrzeba aktywizacji obywatelskiej osób starszych do podejmowania dialogu społecznego w miejscu zamieszkania. Formę realizacji tego dialogu powinny stanowić gminne rady seniorów ${ }^{5}$. W art. 5 c ust. 3 u.s.g. ustawodawca przewidział, że rady te będą miały charakter konsultacyjny, doradczy i inicjatywny. W literaturze słusznie stwierdza się, że przymiotniki te wskazują na funkcje gminnych rad seniorów ${ }^{6}$. Po kilku latach funkcjonowania tej instytucji należy zadać

\footnotetext{
* Artykuł stanowi skróconą wersję badań własnych powstałych w ramach działalności statutowej UKSW.

${ }^{1}$ Dz. U. 2013, poz. 1318; wejście w życie: 30 listopada 2013 r.

2 T.jedn.: Dz. U. 2017, poz. 730 ze zm. (dalej jako: „ustawa o samorządzie gminnym” lub u.s.g.).

${ }^{3}$ M. Augustyniak et al., Gminne rady seniorów - wyktadnia przepisów i efekty ich stosowania. Wzory i schematy działań, Warszawa 2016, s. 15 i n.

4 Jako podstawę prawna powołano art. 18 ust. 1 u.s.g. oraz uchwałę nr XXXIII/262/IV/2003 Rady Miasta Poznania z 18 listopada 2003 r. w sprawie miejskiej strategii polityki społecznej.

${ }^{5}$ Druk nr 1572/VII kadencji Sejmu. Autorzy projektu stwierdzili: „Zadaniem ustawodawcy w tym zakresie powinno być stworzenie jasnych podstaw prawnych umożliwiających praktyczne popularyzowanie idei przedstawicielstwa seniorów przy organach samorządu terytorialnego i powoływanie gminnych rad seniorów. Rady te będą reprezentować interesy i potrzeby starszych mieszkańców wobec władz samorządowych i brać udział w formułowaniu oraz przekazywaniu opinii i stanowisk dotyczących nie tylko strategicznych, ale i bieżących planów rozwoju gminy”.

${ }^{6}$ M. Augustyniak et al., op. cit.; W. Borczyk, D. Jachimowicz, W. Nalepa, Gminne rady seniorów w praktyce - wybrane zagadnienia, Nowy Sącz 2014.
} 
pytanie badawcze, czy gminne rady seniorów spełniają również inne, pozanormatywne funkcje.

Pojęcie funkcji jest jednak wieloznaczne ${ }^{7}$, dlatego już w tym miejscu istnieje potrzeba wskazania, w jakim znaczeniu pojęcie to rozumiane będzie w dalszym wywodzie. Funkcja traktowana będzie jako skutek, czy też inaczej „oznaczenie trwałych następstw społecznych, jakie wiążą się z ustanowieniem

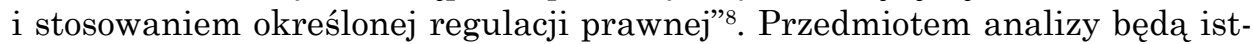
niejace rozwiazania prawne oraz wybrane badania empiryczne pod katem funkcji gminnych rad seniorów rozumianej jako skutek istniejącej regulacji.

Zgodnie z art. 1 u.s.g.: 1) „Mieszkańcy gminy tworzą z mocy prawa wspólnotę samorządową, 2) Ilekroć w ustawie jest mowa o gminie, należy przez to rozumieć wspólnotę samorządową i odpowiednie terytorium”. Przepis ten normuje dwa niezbędne elementy konstrukcyjne polskiego samorządu terytorialnego, tj. element podmiotowy - wspólnotę mieszkańców oraz przedmiotowy - odpowiednie terytorium, będące współcześnie jednostką zasadniczego podziału terytorialnego kraju9. Już sama nazwa „samorząd terytorialny” wskazuje, że elementem tworzącym przestrzenne granice wspólnoty jest podział administracyjny państwa na poszczególne terytoria, podział o tyle uniwersalny, iż przez swoja powszechność wyróżnia samorząd na tle samorządu gospodarczego i zawodowego ${ }^{10}$.

Wspólnota samorządowa to inaczej związek mieszkańców danego obszaru związek o relacjach raczej prawnych niż socjologicznych czy politycznych ${ }^{11}$. Co prawda Konstytucja daje określone wskazówki co do tego, że obszary, w których z mocy prawa osadza się wspólnotę samorządowa, winny być tworzone w oparciu przynajmniej o jedną z więzi: społeczna, gospodarczą lub kulturowa (art. 15 ust. 2 Konstytucji), tak aby unikać tworzenia przypadkowych zbiorowości ludzkich, lecz jednak wspólnota ta ma charakter zmienny, co wynika z czynników migracyjnych i naturalnej zastępowalności pokoleniowej.

Wspólnotę samorządową tworzą osoby fizyczne. Wspólnota składa się zatem z ludzi w różnym wieku, tworzących w mikroskali piramidę wieku. W tym kontekście można stosować przymiotniki syntezujące stan wieku przeważającej części mieszkańców, typu gmina „młoda”, gmina „stara” itp.

Zgodnie z prognozami demograficznymi społeczeństwo polskie, w tym społeczności lokalne (w większości) będą się starzały. Starzenie to będzie miało zarówno charakter indywidualny - odniesiony do poszczególnych członków wspólnoty, jak i demograficzny, dotyczący całego społeczeństwa. Przyczyny starzenia się większości społeczności lokalnych warunkowane są wydłużaniem wieku życia. Przyczyn tego procesu upatruje się także w migracjach wewnętrznych i zewnętrznych. Pierwsze dotyczą migracji ludzi młodych głównie

${ }^{7}$ Z. Ziembiński, O pojmowaniu celu, zadania, roli i funkcji prawa, „Państwo i Prawo” 1987, z. 12 .

${ }^{8}$ M. Walasiak, Analogia w prawie procesowym cywilnym, Warszawa 2013.

9 J. Zimmermann, Prawo administracyjne, Warszawa 2016, s. 264 i n.

${ }_{10}$ A. Agopszowicz, Z. Gilowska, Ustawa o samorzadzie terytorialnym. Komentarz, Warszawa 1997, s. 46.

${ }^{11}$ B. Dolnicki, Samorzad terytorialny, Warszawa 2017, s. 24; A. Agopszowicz, Z. Gilowska, op. cit., s. 61 . 
do dużych ośrodków miejskich na czas studiów i szukania pracy, osiedlanie się w nich i powolne zrywanie kontaktu z dotychczasowym miejscem zamieszkiwania, swoją wspólnotą lokalną. Ważne są także migracje zewnętrzne skutkujące odpływem ludzi młodych poza granice kraju. To z kolei warunkowane jest głównie migracją zarobkową lub ucieczką przed sytuacją prekariatu, czyli niepewnością zarobkową ${ }^{12}$.

Innym, nie mniej ważnym czynnikiem demograficznego starzenia się społeczeństwa jest niewielka liczba urodzeń niemogąca sprostać wymienialności pokoleń. Do czynników pośrednich zaliczyć można także „skokowy”, falowy wzrost liczby osób starszych powodowany wyżami lat powojennych. Czynniki te powodują konieczność uwzględnienia wyzwań stojących przez wciąż starzejącym się społeczeństwem Polski w skali mikrospołecznej, mezospołecznej i makrospołecznej ${ }^{13}$.

Podczas badania funkcji gminnych rad seniorów oraz ich szczególnego otoczenia prawnego uwaga skupi się przede wszystkim na układzie mezospołecznym. W literaturze do podstawowych wyzwań zwiąanych ze starzeniem się społeczności w skali mezospołecznej zalicza się konieczność zapewnienia odpowiedniej do wieku opieki osobom starszym, dostosowanie instytucji opieki i pomocy społecznej, a także medycznej do potrzeb osób starszych, co wiąże się ze specjalizacją tej pomocy zwłaszcza dla subpopulacji osób starszych zaawansowanych wiekiem, sprostanie oczekiwaniom i potrzebom osób starszych, zwłaszcza z rosnacymi aspiracjami tej grupy społecznej, wreszcie przeciwdziałanie ich wykluczeniu na różnych polach, w tym wykluczeniu cyfrowemu. Wyzwania te wiążą się także z potrzebą wsłuchiwania się w głos osób starszych i uwzględniania ich słusznych uwag w procesach planowania, podejmowania decyzji i realizacji (kompleksowość), ale także ujmowanie gminy - nawet jeżeli jest to gmina „stara” - jako wspólnoty lokalnej składającej się również z innych grup wiekowych. Wymaga to z kolei prowadzenia polityki międzypokoleniowej opartej na wartości solidarności społecznej w tym solidarności międzypokoleniowej ${ }^{14}$, a także respektowania zasady zrównoważonego rozwoju (rozumianej szeroko) ${ }^{15}$.

Osoby starsze pozostają więc coraz liczniejszą kohortą wśród mieszkańców gminy i coraz liczniejsza w państwie - a przez to wzrasta ich waga na polu polityk lokalnych i państwowych. Istotność tej grupy nie bierze się jednak wyłącznie z jej liczebności, ale również jakości składowych, jakie moga wnieść jej członkowie do wspólnoty lokalnej. Oczywiście starzenie się niektórych samorządów należy traktować jako realne wyzwanie polityki samorzą-

${ }^{12}$ R. Tomaszewska-Lipiec, Prekarna praca jako produkt wspótczesnej cywilizacji, „Przegląd Pedagogiczny" 2014, nr 2.

${ }_{13}$ M. Mitręga, Konsekwencje procesu starzenia sie dla polityki społeczno-gospodarczej, w: M. Zrałek (red.), Przestrzenie starości, Sosnowiec 2012, s. 16-20.

${ }_{14}$ Zob. możliwy sposób rozumienia tej zasady: P. Dobosz, Sprawiedliwość międzypokoleniowa w prawie administracyjnym, w: M. Kasiński, M. Stahl, K. Wlaźlak (red.), Sprawiedliwość i zaufanie do władz publicznych $w$ prawie administracyjnym, Warszawa 2015, s. 80 i n.

${ }^{15}$ K 23/05, OTK-A 2006, nr 6, poz. 62; zob. też A. Bałaban, Konstytucyjna zasada zrównoważonego rozwoju, w: L. Garlicki, A. Szmyt (red.), Sześć lat Konstytucji Rzeczypospolitej Polskiej. Doświadczenia i inspiracje, Warszawa 2003, s. 20. 
dowej i państwowej, lecz trudno nie dostrzec, że zwiększenie się ilości osób starszych nie generuje wyłącznie problemów, ale stanowi też nowa, pozytywną jakość ${ }^{16}$.

II. Należy przypomnieć, że na podstawie regulacji prawnej gminne rady seniorów w Polsce mogą funkcjonować od 30 listopada 2013 r. ${ }^{17}$ Możliwość ich funkcjonowania na podstawie wyraźnej podstawy prawnej dała nowelizacja ustawy o samorządzie gminnym dokonana ustawą z 11 października 2013 r. o zmianie ustawy o samorządzie gminnym ${ }^{18}$, która do przepisów u.s.g. dodała art. 5c.

Ratio legis wprowadzenia do polskiego porządku prawnego tego przepisu spotkała się z fundamentalną krytyką w doktrynie ${ }^{19}$. Marek I. Mączyński wskazywał, że istnienie gminnych rad seniorów przyczyni się do „,ztucznego podkreślenia dotychczas bliżej nieakcentowanych i nieokreślanych różnic międzypokoleniowych"; jego zdaniem brak sensu istnienia omawianego ciała wynika z możliwości uczestnictwa osób starszych w pracach rady gminy w roli radnych. Autor, tworząc wyraźną opozycję z młodzieżowymi radami gminy, wskazuje: „W przeciwieństwie do młodzieżowych rad gminy tworzenie rad seniorów nie powinno chyba być też uzasadniane potrzebą edukacyjną. Chyba że - gwoli zapewnienia równości - równolegle utworzymy szkoleniowe rady gminy dla pozostałych mieszkańców i grup społecznych". Krytyka dotyczy również możliwości pełnienia przez gminne rady seniorów roli swoistych przetrwalników dla członków partii, którzy nie zostali wybrani do rady gminy w wyborach samorządowych. Dodatkowo autor podkreślał, że paradoksalnie organy te moga służyć do kontrolowania i marginalizowania społeczno-politycznego oddziaływania osób starszych w gminach.

Opinia M. I. Mączyńskiego o wątpliwej ratio legis art. 5c u.s.g. nie przekonuje. Praca $\mathrm{w}$ gminnych radach seniorów ma siłą rzecz innych charakter niż $\mathrm{w}$ radzie gminy, zarówno w zakresie pełnionych funkcji, intensywności prac, jak i odpowiedzialności. Biorąc pod uwagę sytuację psychospołeczną osób starszych (słabnace siły, kłopoty zdrowotne itp.), uczestnictwo w pracach rady gminy może stanowić zbyt duże obciążenie, gdy tymczasem lukę pomiędzy

\footnotetext{
16 „Ludzie starzy pomagaja nam mądrzej patrzeć na ziemskie wydarzenia, ponieważ dzięki życiowym doświadczeniom zyskali wiedzę i dojrzałość. Sa strażnikami pamięci zbiorowej, a więc mają szczególny tytuł, aby być wyrazicielami wspólnych ideałów i wartości, które sa podstawa i reguła życia społecznego. [...] Ludzie starsi dzięki swej dojrzałości i doświadczeniu mogą udzielać młodym rad i cennych pouczeń” - św. Jan Paweł II, List: „Do moich Braci i Sióstr - ludzi w podeszłym wieku!", Watykan 1 października 1999 r., za: http://www.janpawel2.pl [dostęp: 20.03.2017]. Zob. też: I. Lipowicz, Prawo osób starszych do dobrej administracji, w: P. Broda-Wysocki, A. Dylus, M. Pawlus (red.), Dyskryminacja seniorów w Polsce, Warszawa 2016, s. 194.

17 Jednak za ich faktyczny początek funkcjonowania uznaje się 2006 r. O różnych typach gminnych rad seniorów, w tym jednostek pomocniczych, zob. T. Moll, Rada seniorów - sposób realizacji potrzeby zwiększania aktywności osób starszych, „Samorząd Terytorialny” 2015, nr 11, s. $74-75$.

${ }^{18}$ Dz. U. 2013, poz. 1318.

${ }_{19}$ Poniższe cytaty i opis krytyki za: M. I. Maczyński, Komentarz do art. 5(c) ustawy o samorzadzie gminnym, w: P. Chmielnicki (red.), Ustawa o samorzadzie gminnym. Komentarz, Warszawa 2013, Lex/el.
} 
czynnym udziałem w zarządzaniu sprawami wspólnoty a biernością wypełnia właśnie gminna rada seniorów. Należy również stwierdzić, że expressis verbis z przepisu prawnego wynika charakter gminnej rady seniorów jako organu o składzie wybieralnym, a nie pochodzącym z nominacji. To zaś powoduje trudności w zrozumieniu, że w skład gminnej rady seniorów wchodzić będą osoby niewybrane do rady gminy, skoro co do zasady ten sam elektorat gminny będzie posiadał czynne prawo wyborcze. Nawet jednak gdyby tak się zdarzyło, trudno podważać wybór jako niedemokratyczny czy też nieakceptowalny.

Wskazany przepis jest jedyna podstawą prawną funkcjonowania gminnej rady seniorów w polskim porządku prawnym. Należy zgodzić się z Romanem Marchajem, że rady seniorów nie mogą legalnie powstawać ani funkcjonować w powiecie i województwie samorządowym, gdyż brak wyraźnych podstaw ich utworzenia w samorządowych ustawach ustrojowych ${ }^{20}$. Co prawda w literaturze wskazuje się, że przepis ten wkomponowuje się w jeden $\mathrm{z}$ obszarów działalności wspólnoty gminnej, który został określony w art. 7 ust. 1 pkt 17 u.s.g. (wspieranie i upowszechnianie idei samorządowej, w tym tworzenie warunków do działania i rozwoju jednostek pomocniczych i wdrażania programów pobudzania aktywności obywatelskiej), przepis ten jednak samodzielnie nie określa kompetencji do utworzenia gminnej rady seniorów. Należy traktować go zatem jako określenie sprawy, czy lepiej - obszaru działalności organów gminnych, art. 5c u.s.g. zaś jako swego rodzaju doprecyzowanie art. 7 ust. 1 pkt 17 u.s.g. ${ }^{21}$

Zadaniami gminy są: 1) sprzyjanie solidarności międzypokoleniowej oraz 2) tworzenie warunków do pobudzania aktywności obywatelskiej osób starszych w społeczności lokalnej. Trzeba stwierdzić, że tak zarysowane zadania muszą być bezwzględnie realizowane przez organy gminy. Wynika to z samej konstrukcji zadania administracji publicznej rozumianego jako publicznoprawny obowiązek ${ }^{22}$. Cechą charakterystyczną zadania jest jednak pozostawienie otwartego katalogu czynności, którymi może posłużyć się organ administracyjny, byleby czynności te nie wpływały władczo na adresata działań organu administracyjnego, chyba że sam przepis prawa wskazuje na kompetencję, której należy używać, aby zrealizować dane zadanie ${ }^{23}$.

Solidarność co do zasady postrzegana jest jako więź pozytywna, na którą składają się elementy współdziałania, współodpowiedzialności ${ }^{24}$, ale także wyrównawczej sprawiedliwości. Wydaje się, że zadanie sprzyjania solidarności międzypokoleniowej nałożone na gminę odnosi się przede wszystkim do solidarności występującej między pokoleniami współegzystującymi. Widać to

${ }^{20}$ R. Marchaj, Komentarz do art. 5(c) ustawy o samorzqdzie gminnym, w: B. Dolnicki (red.), Ustawa o samorzadzie gminnym, Lex/el., Warszawa 2016.

21 Por. T. Moll, op. cit., s. 66.

${ }^{22}$ Por. np. L. Zacharko, Prywatyzacja zadań publicznych gminy. Studium administracyjnoprawne, Katowice 2000, s. 16; M. Tabernacka, Konstrukcja prawna zadania publicznego, „Acta Universitatis Wratislaviensis" nr 295, Prawo, t. 295, Wrocław 2005, s. 409.

${ }^{23}$ D. Mazurkiewicz, Pojęcie kompetencji w prawie administracyjnym, „Państwo i Prawo” 1988, z. 3, s. 78; K. Bandarzewski, Uczestnictwo organizacji pozarzadowych w realizacji i wykonywaniu zadań pomocy społecznej (wybrane zagadnienia), „Casus” 2003, nr 27, s. 29.

24 P. Dobosz, op. cit. 
wyraźnie, gdy połączy się solidarność międzypokoleniową z sprawiedliwością wyrównawcza, co akcentowano w sejmowym uzasadnieniu projektu nowelizacji, stwierdzając: „osoby starsze maja prawo do sprawiedliwego podziału przestrzeni publicznej, korzystania z infrastruktury edukacyjnej, kulturalnej i sportowo-rekreacyjnej oraz programów sprzyjających ich aktywności społecznej, intelektualnej i fizycznej, a także pomocy gminy w sytuacji zaistnienia braku samodzielności”.

W zakresie solidarności międzypokoleniowej można przyjąć jednak przynajmniej dwie perspektywy osoby starszej - perspektywę bierną i czynną. Pierwsza z nich zakłada konieczność funkcjonowania osoby starszej w przestrzeni urządzanej dla niej, choćby miała ona sprzyjać jej potrzebie i oczekiwaniom. Druga jednak lepiej oddaje charakter wspólnotowy i polega na współdecydowaniu o przestrzeni, a więc aktywnej postawie względem środowiska funkcjonowania osoby starszej. Jest wyrazem dialogu społecznego i stanowi podstawę samorządności i zaangażowania obywatelskiego ${ }^{25}$. W tym zakresie widać sui generis wielofunkcyjność zadania tworzenia warunków do pobudzania aktywności obywatelskiej osób starszych w społeczności lokalnej. Z jednej strony można traktować je jako wyodrębnione zadanie, z drugiej zaś - wpisujące się w perspektywę sprzyjania solidarności międzypokoleniowej.

Zgodnie z regulacją ustawową w skład gminnych rad seniorów wchodzić moga zarówno osoby starsze, jak i przedstawiciele podmiotów działających na rzecz osób starszych, choćby nie zaliczano ich do kategorii osób starszych. W ustawie poza tym brak wyraźnej granicy wieku przy określaniu osób starszych - nie pozostawia raczej wattpliwości, że należy używać tego kryterium przy wyznaczaniu kategorii osób starszych, choć przecież proces starzenia może być postrzegany również z perspektywy ekonomicznej, biologicznej, społecznej i innych. Tymczasem jednak starość winna być postrzegana jako rezultat starzenia się, który to proces rozpoczyna się dość wcześnie w wymiarze chronologicznym ${ }^{26}$. W skład gminnej rady seniorów wchodzić powinni także przedstawiciele organizacji działających na rzecz osób starszych - wykładnia językowa może pozostawiać wątpliwości, że jest to obligatoryjny skład, ustawodawca nie posłużył się tu modalnościa, lecz zastosował kłopotliwy interpretacyjnie spójnik „oraz”. Spójnik ten występować może w znaczeniu koniunkcji lub enumeracji. Interpretacja tego spójnika musi uwzględniać zasady adekwatności tekstu prawnego do zamiaru prawodawcy, z której „wynika, że tekst aktu prawnego powinien być tak zredagowany, by dokładnie odpowiadał zamiarom prawodawcy”"27. Stoję na stanowisku, że użycie słowa „oraz” należy traktować jako wyliczenie w kontekście dążenia do określenia możliwie szerokiego składu gminnej rady seniorów, jednak bez konieczności (jeżeli to niemożliwe) dokooptowywania do jej składu przedstawicieli organizacji działających na jej rzecz.

${ }^{25}$ Druk sejmowy nr 1572/VII kadencji Sejmu.

${ }^{26}$ K. Duda, Proces starzenia się, w: A. Marchewka, Z. Dąbrowski, J. A. Żołądź (red.), Fizjologia starzenia się. Profilaktyka i rehabilitacja, Warszawa 2012, s. 1 i n.

${ }^{27}$ Wyrok NSA z 22 czerwca 2010 r., I GSK 870/09, CBOSA. 
Ustawodawca pluralistycznie stwierdził, że w skład rady, obok seniorów, wchodzić moga przedstawiciele po prostu wszystkich organizacji działających na rzecz osób starszych - to określenie wskazuje na cel działalności podmiotów, abstrahujac od ich struktury organizacyjnej ${ }^{28}$.

III. Zgodnie z art. 5c ust. 3 u.s.g. gminna rada seniorów ma charakter konsultacyjny, doradczy i inicjatywny. Należy zgodzić się z poglądem, że „Ustawodawca nie daje organowi powołującemu radę seniorów uprawnienia do dokonania wyboru roli rady, lecz narzuca ją wprost, wskazując równocześnie trzy funkcje. Trzeba też zwrócić uwagę na brak słowa bądź zwrotu, który uprawniałby właściwy organ powołujący radę seniorów do wyboru jednej czy dwóch spośród wskazanych funkcji. Pozwala to na uznanie rady seniorów jako ciała konsultacyjno-doradczo-inicjatywnego" ${ }^{29}$. Należy jednak wskazać, że zakres i treść regulacji mogą dawać podstawy do poszukiwania innych jeszcze niż wysłowionych przez prawodawcę funkcji powstajacych w praktyce działania rady bez potrzeby ingerencji prawotwórczej rady gminy. Również połączenie tych trzech funkcji w jednym ciele nie przeszkadza ich odrębnemu omówieniu, każda bowiem, zgodnie z założeniem racjonalnego prawodawcy, charakteryzować winna inne skutki. Skutki te moga być rozważane w różnych odniesieniach (płaszczyznach). Dla przedmiotu badań wyodrębniono:

a) płaszczyznę relacji gminna rada seniorów - organy gminy,

b) płaszczyznę relacji gminna rada seniorów - wspólnota samorządowa,

c) płaszczyznę relacji gminna rada seniorów - seniorzy w gminie,

d) płaszczyznę relacji gminna rada seniorów - członkowie gminnej rady seniorów.

\section{Funkcje w płaszczyźnie gminna rada seniorów - organy gminy}

Funkcja konsultacyjna. Należy zgodzić się, że „prowadzenie konsultacji z radą seniorów przez władze gminy to zaczerpnięcie informacji, pozyskanie wiedzy co do stanowiska lokalnego społeczeństwa w zakresie przedmiotu objętego opiniowaniem [...]. Wyniki konsultacji, poza przypadkami jednoznacznie wskazanymi $\mathrm{w}$ przepisach prawnych, nie maja charakteru wiążacego dla władz gminy"30. Wydaje się, że o konsultacje takie może wystapić zarówno każdy organ gminy, jak i sama rada seniorów. W literaturze i orzecznictwie również słusznie wskazuje się, że organ gminy nie ma prawa ograniczać materii, w której będzie działała gminna rada seniorów - „nie mieści się to w pojęciu "powołania rady seniorów" ani też w pojęciu "trybu powoływania członków Rady oraz zasad jej działania“" ${ }^{31}$. Przyjąć zatem należy, że mogą być to wszystkie sprawy lokalne ważne dla wspólnoty oraz - co naturalnie ważne - dla ludzi starszych. Nie ma jednak przeszkód, szczególnie w obliczu trakto-

\footnotetext{
28 Por. szerzej M. Augustyniak et al., op. cit.

${ }^{29}$ M. Augustyniak et al., Rada seniorów jako ciało konsultacyjne, doradcze i inicjatywne, w: eadem et al., op. cit.

30 Ibidem.

31 Ibidem. Wyrok WSA w Gliwicach z 10 marca 2016 r., IV SA/Gl 973/15.
} 
wania rady jako realizującej cel solidarności międzypokoleniowej, a nie tylko pobudzania aktywności ludzi starszych, aby rada ta zabierała głos w sprawach dotyczących np. remontu boiska szkolnego przeznaczonego dla dzieci. Oczywiście sytuacja taka jest dopuszczalna, jednakże z oczywistych względów konsultacje będą raczej się ograniczać do „oddziaływania rady, np. na efektywniejszy podział przestrzeni publicznej, ułatwianie seniorom możliwości korzystania z infrastruktury komunalnej (zwłaszcza kulturalnej, rekreacyjnej czy edukacyjnej)" ${ }^{2}$. Przedmiot konsultacji winien być jednak wyznaczony przez praktykę działania, a nie obowiązujace prawo.

W ogólnopolskich badaniach praktyki konsultacyjnej gminnych rad seniorów wskazuje się, że praktyka ta dotyczy głównie spraw osób starszych ${ }^{33}$, obraz taki wyłania się również z raportu monitorowania osób starszych z 2015 r. ${ }^{34}$, jak i cząstkowych badań własnych. W tym zakresie z grupy ponad 5\% losowo wybranych gmin w Polsce odpowiedzi na internetowa ankietę udzieliło 86 jednostek samorząu terytorialnego. Tylko $\mathrm{w} 18 \mathrm{z}$ nich powołano gminną radę seniorów. W przypadku jednej gminy otrzymano odpowiedź, iż gminna rada seniorów jest w trakcie tworzenia (gmina ta nie wypełniła ankiety). Spośród 18 odpowiedzi o powołaniu gminnej rady seniorów wskazano, iż w 16 przypadkach ciało te pełni funkcję konsultacyjna. Wśród konsultowanych spraw z organami gminy wymieniono m.in.: projekty uchwał, np. projekt statutu miasta, zgłaszanie uwag do przekazanych do zaopiniowania aktów prawa miejscowego, wszystkie sprawy dotyczące środowiska seniorów, lokalne strategie, programy rozwoju, projekty uchwał, tylko działania na rzecz seniorów, programy zdrowotne, społeczne, aktualizacje strategii, akty prawne - uchwały rady miasta, konsultacje kwestii dotyczących działań na rzecz seniorów, konsultacja projektów uchwał oraz wszystkich decyzji podejmowanych przez komisje, konsultacje aktów prawnych dotyczących seniorów.

Funkcja doradcza. Rozróżnienie funkcji doradczej od konsultacyjnej może rodzić pewne problemy, gdyż konsultacje to właściwie wyrażanie opinii o czymś, doradztwo ma również taki charakter. Tak jak w przypadku konsultacji rada nie musi być wzięta pod uwagę. Należy jednak przyjąć, że doradztwo

${ }^{32}$ M. I. Mączyński, op. cit.

${ }^{33} \mathrm{~W}$ ogólnopolskich badaniach dotyczących gminnych rad seniorów jako podlegające konsultacji wskazano konsultacje dotyczace: regulaminu Karty Seniora; aktów prawa miejscowego przygotowywanych przez burmistrza, dotyczących w szczególności sytuacji seniorów, usług cateringowych $\mathrm{w}$ domach dziennego pobytu, projektu uchwały dotyczącej polityki zdrowia, polityki rozwoju, polityki rozwoju kultury, polityki rozwoju edukacji, wdrożenia zintegrowanego systemu opieki nad seniorem, strategii rozwoju miasta, budżetu obywatelskiego, budżetu miasta, programów zdrowotnych, współpracy gminy z organizacjami pozarządowymi oraz innymi podmiotami prowadzącymi działalność pożytku publicznego itp. Tylko w jednym badanym przypadku zanotowana została własna inicjatywa przedłożenia opinii przez radę seniorów dotycząca wzniesienia pomnika poświęconego Zesłańcom Sybiru i Ofiar Katynia”. Za: M. Augustyniak et al., Rada seniorów..., passim.

${ }^{34}$ Informacja o sytuacji osób starszych w Polsce za rok 2015 - przyjęta przez Radę Ministrów w trybie obiegowym 4 listopada 2016 r., przekazana do Sejmu i Senatu 14 listopada 2016 r., https://bip.kprm.gov.pl/kpr/bip-rady-ministrow/informacje-i-sprawozda/4015,informacje. html [dostęp: 1.05.2017]. 
różni się od konsultacji istotnymi cechami. Konsultacje mają charakter raczej punktowy inicjowany zarówno przez organ gminy, jak i gminną radę seniorów. Cechą doradztwa jest pewna ciagłość wyrażająca się w stałej - jeżeli byłaby to nawet potencjalna - obecności przy podmiocie, któremu się doradza ${ }^{35}$. Relacja doradztwa oznacza także - w polskich warunkach założoną przez polskiego ustawodawcę - swego rodzaju przewagę informacyjną lub doświadczenia gminnych rad seniorów. Ustawodawca nie sprecyzował, komu powinna doradzać gminna rada seniorów, należy zatem przyznać, że funkcja ta może być sprawowana w stosunku do organów samorządu terytorialnego. Jeżeli chodzi zaś o zakres doradztwa, to ograniczeniem będzie właściwie zakres spraw przypisanych do gminy i jej organów. Z badań własnych wynika, że w 17 na 18 gminach gminne rady seniorów pełnią funkcję doradcze. Co interesujące, wszystkie gminne rady seniorów doradzały organowi wykonawczemu (17 odpowiedzi), a $10 \mathrm{z}$ nich dodatkowo organowi stanowiącemu.

Funkcja inicjatywna. Ostatnią z obligatoryjnie sprawowanych funkcji jest funkcja inicjatywna. Inicjatywa to pomysł jakiegoś działania, raczej nie zaniechania. $Z$ inicjatywą występuje zawsze pomysłodawca, chociaż może być w tym celu nakłaniany przez podmiot władny do rozstrzygnięcia lub inny podmiot lobbujacy.

Należy zgodzić się, że: „Przyznanie radzie seniorów charakteru inicjatywnego, analogicznie jak w przypadku charakteru doradczego, nie zostało zakreślone przez ustawodawcę, co pozwala na podejmowanie wszelkiego rodzaju inicjatyw zgodnych z zakresem zadań gminy, nie naruszając zasad kompetencyjności organów gminy" ${ }^{36}$. Praktyka działalności wskazuje jednak, że inicjatywy te, inaczej niż zakres konsultowanych aktów, dotyczą w przeważającej większości spraw (wydarzeń) dotyczących osób starszych. To ciekawe, że pomimo braku ustawowych ograniczeń gminne rady seniorów zasadniczo przestrzegaja swojej niepisanej roli jako ciała powołanego do reprezentowania interesów osób starszych w gminie.

W stosunku do władz gminnych gminna rada seniorów może spełniać funkcję nacisku i dzięki temu stać się podmiotem zaliczanym do grupy interesu (pomiędzy obywatelem a władza), a przez to być klasyfikowana jako podmiot społeczeństwa obywatelskiego ${ }^{37}$. Lobbingowy charakter tego ciała wynika zresztą wprost z ustawy. Skoro ustawodawca stwierdza, że w skład gminnej rady seniorów winny wchodzić osoby starsze, a także przedstawiciele podmiotów działających na ich rzecz, trudno spodziewać się, aby w połączeniu

${ }^{35}$ „Z przeprowadzonego badania ankietowego w zakresie charakteru doradczego można zaobserwować powtarzające się praktyki polegające na: zapraszaniu prezydenta miasta/wójta/burmistrza na posiedzenia rad, angażowaniu seniorów fachowców, udziale z głosem doradczym członka rady w posiedzeniach Społecznej Komisji Mieszkaniowej, Gminnej Komisji ds. Rozwiazywania Problemów Alkoholowych, Powiatowej Społecznej Radzie ds. Osób Niepełnosprawnych czy Powiatowej Komisji Bezpieczeństwa i Porządku, udziale w posiedzeniach komisji Rady Miasta, zaangażowaniu członków rady w pracach nad strategią rozwiązywania problemów społecznych”. Ibidem.

${ }^{36}$ M. Augustyniak et al., op. cit.

${ }^{37}$ J. Blicharz, Administracja publiczna i społeczeństwo obywatelskie w państwie prawa, Wroclaw 2012, s. 115 . 
z funkcjami konsultacyjna, doradczą i inicjatywną ciało to nie stanowiło podmiotu nacisku na władzę w sprawach osób starszych.

\section{Funkcje w płaszczyźnie gminna rada seniorów - wspólnota samorządowa}

Osoby wchodzące w skład gminnej rady seniorów pełnią podwójną rolę: z jednej strony przynależą do wspólnoty samorządowej, z drugiej zaś - sa członkami specjalnego ciała tej wspólnoty, która ma organom jednostki samorząu terytorialnego doradzać, pełnić funkcję konsultacyjna oraz inicjatywną. Bez wątpienia celem ustawodawcy było utworzenie ciała, które „zawalczy” o prawa grupy osób starszych w gminie. Może to powodować konflikty z interesami innych grup wspólnoty samorządowej. Wydaje się jednak, że zabieganie o dostrzeżenie potrzeb osób starszych winno odbywać się w granicach interesu wspólnoty samorządowej. Oznacza to, że podwójną rolę, w jakiej występuje osoba starsza zasiadająca $\mathrm{w}$ omawianym organie, winna spajać konstrukcja interesu lokalnego. W płaszczyźnie gminna rada seniorów - wspólnota samorządowa bezpośrednio najbardziej konfliktogenną wydaje się funkcja inicjatywna, gdyż w sposób najpełniejszy wyraża się ona w wyrażeniu potrzeb i oczekiwań osób starszych względem wspólnego środowiska życia. W ten sposób wskazać należy, że swoistym „wentylem bezpieczeństwa” będzie uwzględnianie zasady solidarności międzypokoleniowej. Realizacja, a zarazem właściwie rozumianą współpracą międzypokoleniową moga być praktykowane w niektórych gminach spotkania z całej gminnej rady seniorów lub jej przedstawicieli z młodzieżową radą gminy.

Analizując funkcję inicjatywna, wskazać należy, że zasadniczo gminne rady seniorów nie sa inicjatorami przedsięwzięć dotyczących całej wspólnoty samorządowej, choć i tu znajdują się wyjątki, jak np.: publiczna kwesta na rzecz odnowienia jednego z grobów w gminie, utworzenie bulodromu, inicjatywa organizacji dni miasta, inicjatywa konkursu wiedzy o mieście.

Wśród odpowiedzi na własną ankietę respondenci wskazywali, że gminna rada seniorów spełnia również funkcje konsultacyjną względem wspólnoty samorządowej - wymieniano tu w jednym przypadku: konsultacje $\mathrm{z}$ organizacjami pozarządowymi działającymi na terytorium gminy i skupiającymi seniorów.

W płaszczyźnie tej najwidoczniej ujawnia się pozanormatywna funkcja budowania społeczeństwa obywatelskiego. „Poczucie członkostwa we wspólnocie jest niezmiennie ważne z punktu widzenia tożsamości jednostki jako integralnej części zbiorowości. Poprzez bezpośrednie zaangażowanie każdego członka ogółu dochodzi do budowania społeczeństwa obywatelskiego. [...] Zasada dobra wspólnego, rozumiana jako współodpowiedzialność za losy wspólnoty, oznacza pełne zaangażowanie na rzecz społeczności lokalnej zarówno w zakresie korzystania ze swoich praw, jak również kreowania wizerunku wspólnoty, wpływania na decyzje podejmowane wewnątrz" ${ }^{38}$.

${ }^{38}$ D. Kalita, K. Rawska, G. Staniszewska, Uczestnictwo osób starszych w życiu społecznym, w: B. Szatur-Jaworska (red.), Strategie działania w starzejacym się społeczeństwie. Tezy i rekomendacje, Warszawa 2012, s. 19-20. 


\section{Funkcje w płaszczyźnie gminna rada seniorów - seniorzy w gminie}

Wyróżnienie tej płaszczyzny relacji może nastręczać pewne trudności, można ją bowiem traktować jako rodzaj działalności na rzecz członków wspólnoty samorządowej. Wyodrębnienie jednak określonej kategorii podmiotów ze wspólnoty pozwala wskazać specyfikę funkcji w tej płaszczyźnie. Praktyka działania gminnych rad seniorów wskazuje, że w płaszczyźnie tej nacisk położony jest bowiem na funkcję inicjatywna.

Badania własne wskazały, że tylko w jednym przypadku gminna rada seniorów pełni funkcję konsultacyjną w stosunku do innych seniorów w gminie (,pełnienie dyżurów konsultacyjnych dla starszych mieszkańców miasta”), choć wydaje się, że chodzi raczej o jakiś rodzaj poradnictwa (realizację funkcji doradczej).

W odpowiedziach dotyczących funkcji inicjatywnej wskazano m.in: stworzenie informatora dla seniorów, tworzenie ulotek informacyjnych dla seniorów, stworzenie/przystapienie do programu Karta Seniora, utworzenie dziennego domu pobytu, organizację dni seniora, stworzenie programu polityki senioralnej w mieście, wolontariat seniorów, upowszechnienie „Koperty życia”, utworzenie oddziału geriatrycznego, utworzenie centrum senioralnego, utworzenie programu senioralnego, ulgi dla seniorów, konkurs poetycki dla seniorów, kino dla seniorów, kawiarenka dla seniorów, turniej sportowy dla seniorów, inicjatywa organizacji debaty publicznej na temat sytuacji osób starszych, warsztaty komputerowe dla seniorów.

\section{Funkcje w płaszczyźnie gminna rada seniorów - członkowie gminnej rady seniorów}

W literaturze podkreśla się, że aktywność osób starszych ma różne funkcje (skutki). Zasadniczo aktywizacja ludzi starszych powoduje przeciagnięcie w czasie pierwszej fazy starzenia się polegającej na aktywności jednostki. Odwleka się tym samym faze druga polegająca na wycofywaniu się, a przez to przyjęciu stylu życia określanego stylem „bujanego fotela” ${ }^{39}$. Sama zaś aktywność przekłada się szeroko na jakość życia osób starszych w postaci kompensacji, edukacji, adaptacji, rewitalizacji, integracji ${ }^{40}$. W odniesieniu do specyfiki gminnych rad seniorów szczególnego znaczenia nabierają funkcja kompensacyjna, adaptacyjna, integracyjna.

Jako że członkowie rady seniorów są członkami wspólnoty samorządowej, można stwierdzić, iż skutki działalności rady będą wpływać na ich życie. Członkostwo w gminnej radzie seniorów wpływa na aktywność osób starszych, $\mathrm{w}$ ich budżecie czasu pojawia się nowa pozycja zwiazzana $\mathrm{z}$ uczestnictwem w spotkaniach lub opracowywaniem dokumentów związanych z działalnością

${ }^{39}$ I. Iwasyk, Rola uniwersytetu trzeciego wieku $w$ marginalizacji osób starszych, w: P. Broda-Wysocki, A. Dylus, M. Pawlus (red.), Dyskryminacja seniorów w Polsce. Diagnoza i przeciwdziatanie, Warszawa 2016, s. 218.

${ }^{40}$ Ibidem, s. 219. Dalsze nazwy funkcji za: ibidem. 
gminnej rady seniorów. Tym samym w omawianej płaszczyźnie uwidaczniają się w sposób wyraźny pozanormatywne funkcje gminnych rad seniorów. Własne badania praktyki działalności gminnych rad seniorów wskazuja, że w niektórych przypadkach gminna rada organizuje dla swoich członków spotkania towarzyskie, jak wyjazdy, zajęcia rekreacyjne - w badaniach własnych na 18 powołanych rad funkcję taką wskazało $8 \mathrm{z}$ nich. Oznacza to, że gminne rady seniorów spełniaja pozanormatywną funkcję integracyjną. Można funkcję tę traktować jako skutek (odmianę) wewnętrzną funkcji inicjatywnej, wszak pojęcie funkcja inicjatywna można rozumieć jako inicjatywa o charakterze zewnętrznym, jak i wewnętrznym. Wydaje się jednak celowe jej odróżnienie w sytuacji, gdy inicjatywa wyjazdu czy wspólnego spotkania jest limitowana do osób wchodzących w skład gminnej rady seniorów, a poza tym odróżnia się swoim charakterem od inicjatyw podejmowanych dla społeczności lokalnej.

Gminne rady seniorów w stosunku do swoich członków pełnią również funkcję adaptacyjna. Rodzą bowiem potrzebę przystosowania się do nowych warunków życiowych, przyjęcia na siebie nowych, określonych ról społecznych, być może już nie tak intensywnych jak niegdyś, jednak utrzymujących stałe pobudzenie organizmu i jego aktywność fizyczną i psychiczna. W tym kontekście trudno zgodzić się z tą częścią krytyki instytucji gminnych rad seniorów Andrzeja Mączyńskiego, w której twierdzi, że osoby starsze moga przecież swobodnie być wybierane i uczestniczyć w pracach rady gminy - chodzi bowiem o inny sposób intensywności prac gminnej rady seniorów.

Warto wskazać również na fu $\mathrm{nkcję} \mathrm{kompensacji,} \mathrm{a} \mathrm{więc} \mathrm{procesu} \mathrm{pole-}$ gającego na wypełnianiu straty pełnionych dotychczas innych ról społecznych, szczególnie ról zawodowych.

Nie bez znaczenia moga być również funkcje wypełniane pośrednio, tj. edukacyjna, związana z funkcją adaptacyjna - polegająca na zdobyciu wiedzy o procesach partycypacji, $\mathrm{w}$ tym wpływania na procesy zachodzące w gminie, oraz rewitalizacyjna - będąca szczególnie pochodną funkcji integracyjnej i aktywizującej, oznaczająca poprawę kondycji psychofizycznej osób zaangażowanych w gminną radę seniorów.

IV. Analiza funkcji pełnionych przez gminne rady seniorów w określonych płaszczyznach pozwala podjąć próbę wyciągnięcia następujących wniosków:

a) ustawodawca uregulował zamknięty katalog funkcji gminnych rad seniorów, określając je jako konsultacyjną, doradczą i inicjatywną;

b) natężenie funkcji konsultacyjnej i doradczej ujawnia się najpełniej w płaszczyźnie relacji gminna rada seniorów - organy gminne;

c) funkcja inicjatywna jest realizowana w przeważającej większości w płaszczyznach relacji gminna rada seniorów - seniorzy w gminie;

d) można wykazać również istnienie pozanormatywnych funkcji gminnych rad seniorów:

- funkcji nacisku w płaszczyźnie gminna rada seniorów - organy gminy;

- funkcji budowania społeczeństwa obywatelskiego w płaszczyźnie gminna rada seniorów - wspólnota samorządowa; 
- funkcji aktywizującej, integracyjnej, adaptacyjnej, rewitalizującej i edukacyjnej ${ }^{41} \mathrm{w}$ płaszczyźnie gminna rada seniorów - członkowie gminnej rady seniorów.

Powyższe konstatacje prowadzą do ogólnego wniosku, że gminne rady seniorów w Polsce pełnia więcej funkcji, niż zakładał ustawodawca $\mathrm{w}$ art. 5c u.s.g. Jednocześnie niektóre z nich sugerowane były na długo przed powstaniem normatywnej podstawy ich funkcjonowania ${ }^{42}$. Ciała te maja potencjał silnego oddziaływania aktywizujacego na ludzi starszych w gminie, a przez to przyczyniania się do wydłużenia okresu aktywności ludzi starszych. Gminne rady seniorów maja zatem potencjał, aby przyczyniać się do „zdrowego” starzenia się, a przez to stać się kolejnym czynnikiem wydłużającym wiek życia w Polsce.

dr Radostaw Mędrzycki

Uniwersytet Kardynała Stefana Wyszyńskiego w Warszawie

r.medrzycki@uksw.edu.pl

\section{FUNCTIONS OF GMINA SENIOR COUNCILS}

Sum mary

The aim of the article was to show the normative and non-normative functions of gmina senior councils in Poland. We have analysed the social environment of gmina senior councils and the normative grounds on which the councils function. For the purpose of this article, the following issues has been highlighted: a) the area of relations of the gmina senior council and gmina authorities; b) the relations of the gmina senior council and the self-government community; c) the relations of the gmina senior council and the local senior citizens; d) the relation between the gmina senior council and its members. The research shows that, apart from the particular functions of the gmina senior councils (consulting, advising, initiative), such bodies also carry out a number of additional functions, such as: pressurisation, the establishment of the civil society, activisation, integration, adaptation, revitalisation and education.

${ }^{41}$ Funkcja kompensacyjna, edukacyjna, adaptacyjna, rewitalizacyjna, adaptacyjna wymieniane są w literaturze jako funkcje związane z aktywnością osób starszych: tak I. Iwasyk, op. cit., s. 219 .

${ }^{42}$ Por. przyp. 4. 
